\title{
The Impact of Purchase-Decision Involvement on Purchasing Intention: The Mediating Effect of Customer Perceived Value
}

\author{
Yabing Liu ${ }^{1, a}$, Hongliang $\mathrm{Yu}^{1, \mathrm{~b}^{*}}$ and Haiwei Huang ${ }^{1, \mathrm{c}}$ \\ ${ }^{1}$ Zhejiang University, College of Civil Engineering and Architecture, Hangzhou, Zhejiang, China \\ aliuyabing@zju.edu.cn, byhl@zju.edu.cn, czju_hhw@163.com
}

Keywords: Customer perceived value; Purchase-decision involvement; Purchasing intention; Commodity housing

\begin{abstract}
The study explores the influence of purchase-decision involvement on purchase intention in the process of commercial residential purchasing from the perspective of customer perceived value. The aim of the study is to construct a model in which the purchase-decision involvement indirectly influences the purchase intention through the customer perceived value. First of all, the purchase-decision involvement scale, the customer perceived value scale and the purchase intention scale of the commercial residential buildings were constructed and tested. Data from a sample of 133 buyers showed that purchase-decision involvement positively influenced purchase intentions and customers perceived value played a mediating role in this positive relationship.
\end{abstract}

\section{Introduction}

The study of involvement originated in social psychology, and it was introduced into the field of consumer behavior in the 1960s. Involvement has been defined in various ways. Zaichkowsky defined involvement as the perception of one's own things based on intrinsic needs, values and interests, and categorized involvement into product involvement, advertisement involvement and purchase involvemen $\mathrm{t}$ [1]. Mittal explicitly distinguished between purchase involvement and product involvement, and developed a scale for "purchase-decision involvement" [2]. Purchase-decision involvement has been defined as the consumer's interest and attention in purchasing decision-making tasks. Slama \& Tashchian pointed out that the level of involvement affected the entire process of consumption from initial information collection to post-purchase evaluation [3]. Purchase-decision involvement is related to product categories, so we attempts to test the effect of purchase-decision involvement on purchase intention in the area of commodity housing. In this study, we also introduce the variable of customer-perceived value.

The customer perceived value refers to the consumer's overall assessment of the products or services based on their trade-offs between what is received and what is given from Zeithaml [4]. Based on the definition, we defines residential customer perceived value as buyers' subjective evaluation of a particular commodity residential based on the benefits they perceived in the product relative to the sacrifice they perceived by paying the price. Sheth, Newman, and Gross put forward five kinds of perceived values that affect customer's consumption behavior: functional value, social value, emotional value, epistemic value and conditional value [5]. Sweeney and Soutar further divided functional value into two dimensions: functional value quality factor and functional value price factor. They constructed the customer perceived value PERVAL model, including emotional value, emotional value, social value, functional value - price / value for money and functional value - quality / performance [6].

Researches supported the positive impact of customer perceived value on purchasing intention in the field of real estate. Deng Juanhong (2014) constructed a model of the impact of perceived value, perceived benefit and perceived risk on purchasing intention of ordinary commercial housing. It's pointed that perceived value is the main factor affecting the purchase of commercial housing, and perceived value is affected by perceived benefits, perceived risks and perceived costs [7]. Lv Niping and Liu Yifei conducted a survey of 112 customers and found that real estate promotion strategies have a positive impact on customer purchasing intentions, and customer perceived value plays an intermediary role [8]. Zhang Min (2015) surveyed 529 customers from 18 sales offices, showing that 
residential customer perceived value plays an intermediary role in the positive impact of customer participation on purchasing intention [9].

The literature suggests that involvement has a positive impact on purchase intention [10-11]. The current study conducts an empirical investigation of the relationship among the three variables of purchase-decision involvement, customer perceived value and purchase intention in the commercial residential market to explore the mediating effect of customer perceived value.

\section{Models and Assumptions}

Based on the review of the literature, the current study proposes the conceptual model shown in Fig. 1. The independent variable considered in this study is purchase-decision involvement and the dependent variable analyzed is purchase intention. The mediating variable is customer perceived value, including four dimensions of quality value, economic value, social value and emotional value. The hypotheses are stated as follows:

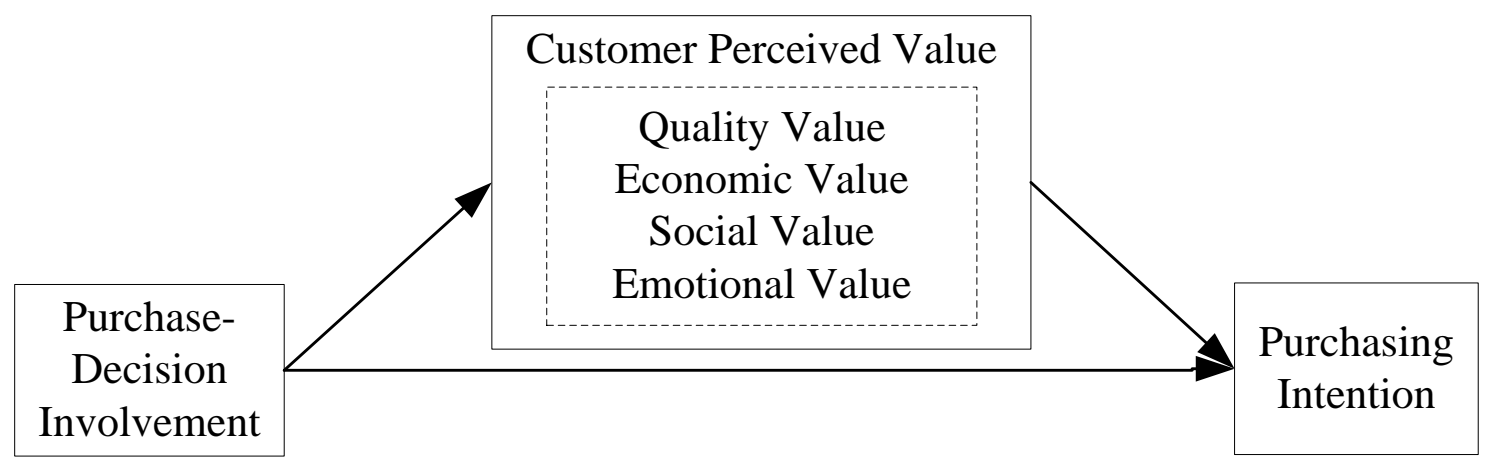

Figure 1. Research framework

H1: Purchase-decision involvement has a positive impact on purchase intention.

$\mathrm{H} 2$ : Purchase-decision involvement has a positive impact on customer perceived value.

H2a: Purchase-decision involvement has a positive impact on customer perceived quality value.

$\mathrm{H} 2 \mathrm{~b}$ : Purchase-decision involvement has a positive impact on customer perceived economic value.

$\mathrm{H} 2 \mathrm{c}$ : Purchase-decision involvement has a positive impact on customer perceived social value.

$\mathrm{H} 2 \mathrm{~d}$ : Purchase-decision involvement has a positive impact on customer perceived emotional value.

H3: Customer perceived value has a positive impact on purchase intention.

H3a: Customer perceived quality value has a positive impact on purchase intention.

H3b: Customer perceived economic value has a positive impact on purchase intention.

H3c: Customer perceived social value has a positive impact on purchase intention.

H3d: Customer perceived emotional value has a positive impact on purchase intention.

H4: Customer perceived value mediates the relationship between purchase-decision involvement and purchase intention.

H4a: Customer perceived quality value mediates the relationship between purchase-decision involvement and purchase intention.

H4b: Customer perceived economic value mediates the relationship between purchase-decision involvement and purchase intention.

H4c: Customer perceived social value mediates the relationship between purchase-decision involvement and purchase intention.

H4d: Customer perceived emotional value mediates the relationship between purchase-decision involvement and purchase intention.

\section{Method}

The study adopted a questionnaire survey. All items used measurement by Likert scale of 1 to 7 
representing an increasing degree of agreement. The measurements of purchase-decision involvement refer to the Purchase-Decision Involvement developed by Mittal [2], including 5 items for commercial residential buildings. The customer perceived value measurement using the four-dimensional model of Sweeney and Soutar [6], namely quality value, price value, social value and emotional value, contains a total of 13 items. Purchase intention is measured by three aspects: consider the purchase, recommended purchase and premium purchase.

We used convenient sampling methods in non-probabilistic sampling and selected the participants who were interested in the purchase of commercial housing with a certain economic base, and had concerned about a particular real estate. A total of 150 questionnaires were distributed, and 133 questionnaires were found valid $(88.7 \%)$.

\section{Results}

Reliability Analyses. Cronbach's $\alpha$ coefficient was used to test the reliability of the scales. It is generally considered that Cronbach's $\alpha$ is between 0.7 and 1 with high reliability. The results showed that the Cronbach's $\alpha$ of purchase-decision involvement, customer perceived value and purchase intention were $0.766,0.926$ and 0.764 respectively. For the customer perceived value, Cronbach's $\alpha$ of quality value, economic value, social value and emotional value were $0.851,0.830,0.909,0.889$ respectively. Therefore, the scale used in this study had high reliability and the questionnaire items have good internal consistency.

Validity Analyses. Exploratory factor analysis was used to evaluate the structural validity of the customer perceived value scale. The Kaiser - Meyer - Olkin (KMO) measure of sampling adequacy $(=0.886)$ and Bartlett's test of sphericity $(p<0.001)$ confirmed that the sample was suitable for principal component analysis. Principal component analysis showed that there were four main factors (Table 1). Each items were attributed to factors with loading at least 0.7 , indicating that the items have a high explanatory power of the corresponding factors. At the same time, no significant cross-factor loading occurred with the factor loading is less than 0.4 in the irrelevant factor. Attribution of the items to their factors showed that the first factor covers social value, the second factor covers quality value, the third factor covers economic value, and the fourth factor covers emotional value.

Table 1 The results of exploratory factor analysis of customer perceived value

\begin{tabular}{cccccc}
\hline \multirow{2}{*}{ Variable } & \multirow{2}{*}{ Items } & \multicolumn{4}{c}{ Component } \\
\cline { 3 - 6 } & & Factor 1 & Factor 2 & Factor 3 & Factor 4 \\
\hline Quality Value & PV1 & 0.085 & 0.747 & 0.187 & 0.364 \\
& PV2 & 0.203 & 0.863 & 0.174 & 0.212 \\
Economic Value & PV3 & 0.169 & 0.809 & 0.239 & 0.117 \\
& PV4 & 0.148 & 0.199 & 0.824 & 0.171 \\
& PV5 & 0.235 & 0.143 & 0.767 & 0.201 \\
Social Value & PV6 & 0.272 & 0.289 & 0.761 & 0.203 \\
& PV7 & 0.828 & 0.212 & 0.254 & 0.234 \\
& PV8 & 0.874 & 0.121 & 0.191 & 0.181 \\
& PV9 & 0.901 & 0.182 & 0.154 & 0.147 \\
& PV10 & 0.778 & 0.078 & 0.188 & 0.284 \\
& PV11 & 0.331 & 0.172 & 0.362 & 0.727 \\
& PV12 & 0.297 & 0.340 & 0.208 & 0.770 \\
& PV13 & 0.229 & 0.257 & 0.165 & 0.838 \\
\hline
\end{tabular}

Mediating Effect of Customer Perceived Value. We used regression analysis to test the intermediary role of customer perceived value between purchase-decision involvement and purchase intention. The analysis results are shown in Table 2. Model 1 3 takes purchase-decision involvement as independent variable, purchase intention as dependent variable, and customer perceived quality 
value as mediating variable, and carries out three-step regression analysis. In the first step, Model 1 shows that purchase-decision involvement has a significant positive impact on purchase intention $(\beta=$ $0.315, t=2.680, p<0.05)$, so hypothesis H1 is accepted. In the second step, Model 2 shows that purchase-decision involvement has a significant positive effect on quality value $(\beta=0.598, t=5.382, p$ $<0.001$ ), so hypothesis $\mathrm{H} 2 \mathrm{a}$ is accepted. In the third step, Model 3 tests the effect of purchase-decision involvement and quality value on purchase intention at the same time and finds that purchase-decision involvement has no significant effect on purchase intention $(\beta=-0.009, t=-0.081, p>0.1)$, while quality value has a significant positive impact on purchase intention $(\beta=0.542, t=6.803, p<0.001)$. It means customer perceived quality value plays a complete intermediary role in the impact of purchase-decision involvement on purchase intention, so hypothesis $\mathrm{H} 3 \mathrm{a}$ and $\mathrm{H} 4 \mathrm{a}$ are accepted. In the same way, model 4 and model 5, model 6 and model 7, model 8 and model 9 respectively test the intermediary role of economic value, social value and emotional value. The results show that economic value and emotional value both play a complete intermediary role in the impact of purchase-decision involvement on the purchase intention, so hypothesis $\mathrm{H} 3 \mathrm{~b}, \mathrm{H} 4 \mathrm{~b}, \mathrm{H} 3 \mathrm{~d}$ and $\mathrm{H} 4 \mathrm{~d}$ are accepted. However, the regression coefficient of purchase-decision involvement with purchase intention is not significant $(\beta$ $=0.211, t=1.753, p>0.1)$ in model 6 , while the regression coefficient of social value with purchase intention is significant $(\beta=0.502, t=6.796, p<0.001)$ in model 7. Then we conducted a Sobel test to prove that the mediating effect of customer perceived social value is not significant $\left(s_{a}=0.120, s_{b}=\right.$ $0.074, z=1.702>0.1$ ), so $\mathrm{H} 3 \mathrm{c}$ and $\mathrm{H} 4 \mathrm{c}$ are rejected.

Table 2 The results of mediate effect

\begin{tabular}{|c|c|c|c|c|c|c|c|c|c|}
\hline & Model 1 & Model 2 & Model 3 & Model 4 & Model 5 & Model 6 & Model 7 & Model 8 & Model 9 \\
\hline Variable & $\begin{array}{l}\text { Purchase } \\
\text { Intention }\end{array}$ & $\begin{array}{l}\text { Quality } \\
\text { Value }\end{array}$ & $\begin{array}{l}\text { Purchase } \\
\text { Intention }\end{array}$ & $\begin{array}{l}\text { Economi } \\
\text { c Value }\end{array}$ & $\begin{array}{l}\text { Purchase } \\
\text { Intention }\end{array}$ & $\begin{array}{l}\text { Social } \\
\text { Value }\end{array}$ & $\begin{array}{l}\text { Purchase } \\
\text { Intention }\end{array}$ & $\begin{array}{c}\text { Emotiona } \\
1 \text { Value }\end{array}$ & $\begin{array}{l}\text { Purchase } \\
\text { Intention }\end{array}$ \\
\hline (Constant) & $\begin{array}{c}2.573 * * * \\
(3.827)\end{array}$ & $\begin{array}{c}1.513 * \\
(2.381)\end{array}$ & $\begin{array}{l}1.753 * * \\
(2.961)\end{array}$ & $\begin{array}{c}2.458 * * * \\
(4.176)\end{array}$ & $\begin{array}{l}1.313^{*} \\
(2.045)\end{array}$ & $\begin{array}{c}2.703 * * * \\
(3.938)\end{array}$ & $\begin{array}{c}1.217 * \\
(1.985)\end{array}$ & $\begin{array}{c}2.264 * * * \\
(3.372)\end{array}$ & $\begin{array}{l}1.388^{*} \\
(2.314)\end{array}$ \\
\hline $\begin{array}{l}\text { Purchase- } \\
\text { Decision }\end{array}$ & 0 315** & 0 508*** & - 0000 & $0168 * * *$ & 0075 & 0211 & 0 210* & $0125 * * *$ & 0087 \\
\hline $\begin{array}{c}\text { Involveme } \\
\mathrm{nt}\end{array}$ & $(2.680)$ & $(5.382)$ & $(-0.081)$ & $(4.544)$ & $(0.664)$ & (1.753) & $(2.043)$ & $(3.706)$ & $(0.827)$ \\
\hline $\begin{array}{l}\text { Quality } \\
\text { Value }\end{array}$ & & & $\begin{array}{c}0.542^{* * * *} \\
(6.803)\end{array}$ & & & & & & \\
\hline $\begin{array}{l}\text { Economic } \\
\text { Value }\end{array}$ & & & & & $\begin{array}{c}0.513^{* * * *} \\
(5.725)\end{array}$ & & & & \\
\hline $\begin{array}{l}\text { Social } \\
\text { Value }\end{array}$ & & & & & & & $\begin{array}{c}0.502 * * * \\
(6.796)\end{array}$ & & \\
\hline $\begin{array}{l}\text { Emotional } \\
\text { Value }\end{array}$ & & & & & & & & & $\begin{array}{c}0.523 * * * \\
(6.986)\end{array}$ \\
\hline$R^{2}$ & 0.052 & 0.181 & 0.301 & 0.136 & 0.243 & 0.023 & 0.300 & 0.095 & 0.311 \\
\hline$F$ & $7.184 * *$ & $\begin{array}{c}28.965 * * \\
*\end{array}$ & $\begin{array}{c}27.976 * * \\
*\end{array}$ & $\begin{array}{c}20.652 * * \\
*\end{array}$ & $\begin{array}{c}20.853 * * \\
*\end{array}$ & 3.074 & $\begin{array}{c}27.921 * * \\
*\end{array}$ & $\begin{array}{c}13.737 * * \\
*\end{array}$ & $\begin{array}{c}29.303 * * \\
*\end{array}$ \\
\hline
\end{tabular}

Note: $(1) * p<0.05, * * p<0.01, * * * p<0.001 ;$ (2) $t$ in brackets.

\section{Conclusions}

Through empirical research, we find that purchase-decision involvement has a significant positive effect on purchase intention in the process of commercial residential purchase, and customer perceived value plays an intermediary role in this relationship. Specifically, the quality value, economy value and 
emotional value of customer perceived value play a complete intermediary role, and the social value do not play an intermediary role.

\section{References}

[1] J.L. Zaichkowsky: Journal of Consumer Research, Vol. 12 (1985) No.3, p.341.

[2] B. Mittal: Psychology \& Marketing, Vol. 6 (1989) No.2, p.147.

[3] M.E. SlamaandA. Tashchian: Journal of Marketing, Vol. 49 (1985) No.1, p.72.

[4] V.A. Zeithaml: Journal of Marketing, Vol. 52 (1988) No.3, p.2.

[5] J.N. Sheth, B.I. Newman and B.L. Gross: Journal of Business Research, Vol. 22 (1991) No.2, p. 159.

[6] J.C. Sweeney and G.N. Soutar: Journal of Retailing, Vol. 77 (2001) No.2, p.203.

[7] J.H. Deng: Study on the Influencing Factors of Consumer Purchasing Intention to the Ordinary Commodity Housing Based on Perceived Value (MS., Nanjing University of Finance \& Economics, China, 2014). (In Chinese)

[8] N.P. Lv and Y.F. Liu: Economic Forum, (2012) No.12, p.144. (In Chinese)

[9] M. Zhang: Research on the Effect of Residential Customer Participation on Purchase Intention (Ph.D., Jiangxi University of Finance \& Economics, China, 2015). (In Chinese)

[10]Z.F. Liao: The Study of Consumers' Purchase Motivation, Cognition, Involvement and Intention of Bancassurance (MS., Chaoyang University of Technology, Taiwan, China, 2004). (In Chinese)

[11]L.X. Xiang: The Effects of Brand Image and Involvement on Purchasing Intention - in Tablets Market (MS., National Chiao Tung University, Taiwan, China, 2013). (In Chinese) 